\title{
NYMPHAEA L. GENUS IN THE DANUBE DELTA, ROMÂNIA
}

\author{
Anca SÂRBU $^{1 *}$, Ion SÂRBU ${ }^{2}$, Anca Monica PARASCHIV ${ }^{1}$, Daniela Clara MIHAI ${ }^{1}$ \\ ${ }^{1}$ University of Bucharest, Faculty of Biology and Botanical Garden "Dimitrie Brandza” - Romania \\ ${ }^{2}$ Botanical Garden “Anastasie Fătu” of the University “Alexandru Ioan Cuza”, Iaşi - Romania \\ *Corresponding author. E-mail: anchusa24@yahoo.com
}

\begin{abstract}
This paper is focused on the two species of the Nymphaea genus, present in the flora of the Danube Delta, respectively Nymphaea alba L. and N. candida C. Presl. The paper has several objectives as follows: i) to illustrate the morphological identification features mentioned in the literature for Nymphaea alba and N.candida, using material collected from the Danube Delta, ii) to complete the existing information with anatomical-histological data regarding the structure of the lamina and the petiole, with emphasis on the particularities of the mechanical, assimilating and conducting tissues of the two hydrophytes, iii) to present and characterize a variety of the taxon Nymphaea candida Nymphaea candida var. undulatifolia var. nova, identified in 2012, in the Danube Delta on the Bărbos Canal and the Letea Canal, with a confirmed presence in the period 2012-2015, 2017-2019.
\end{abstract}

Keywords: anatomy, aquatic plants, identification features, morphology, new taxa.

\section{Introduction}

Nymphaeaceae are aquatic dicotyledons, rarely amphibians [SĂVULESCU (ed.), 1952-1976], well represented in the warm climatic areas in the world.

According to the specialised literature [CIOCÂRLAN, 1994; CIOCÂRLAN \& al. 1998; CIOCÂRLAN, 2009; SÂRBU \& al. 2013; SĂVULESCU (ed.), 1952-1976], Fam. Nymphaceae Salisb., is represented in the Flora of Romania by: Nelumbo Adams. (naturalized plants), Nuphar Sm. and Nymphaea L. (spontaneous plants). The Nymphaea genus includes three species: Nymphaea lotus var. thermalis (DC.) Tuzs., Nymphaea alba L. and Nymphaea candida J. Presl. Rostl. Out of these, two can be found in the Danube Delta: Nymphaea alba and Nymphaea candida [CIOCÂRLAN, 2009; SÂRBU, 2006; SÂRBU \& al. 2011; SÂRBU \& al. 2013; SÂRBU, 2015]. For Nymphaea alba it is mentioned in the Danube Delta and the variety minoriflora (Barb.) A. et G. Syn. [SĂVULESCU (ed.), 1952-1976].

Nymphaea alba and Nymphaea candida are perennial, rooted hydrophytes with rhizome, large floating leaves, long petioles and white flowers, which stand above the water, supported by long floral peduncles. The same characteristics define the plants of Nymphaea alba var. minoriflora, except for the fact that they are shorter and the leaves and flowers are smaller compared to the size of the type [SĂVULESCU (ed.), 1952-1976].

Nymphaea alba differs from Nymphaea candida in terms of morphological characteristics [MUNTENDAM \& al. 1996]. In this sense, the data from the literature document the taxonomic utility of a wide range of morphological identification characters: nervation, shape of the flower base, shape of internal stamens, shape and color of the stigma, number of lobes of the stigma, shape of the gynoecium in longitudinal section, shape and pollen architecture, fruit shape [KABÁTOVÁ \& al. 2014; MUNTENDAM \& al. 1996; NOWAK \& al. 2010; SÂRBU, 2015; SÂRBU \& al. 2013; VOLKOVA \& SHIPUNOV, 2007; WATSONA \& DALLWITZ, 1992]. 
Despite being based on the same organization plan, the histo-anatomical structure of the vegetative body of Nymphaea alba and Nymphaea candida plants [SCHNEIDER \& WILLIAMSON, 1993; STRASBURGER \& al. 1999] present some differences, often dimensional or quantitative, which address especially the lamina, petiole and floral peduncle [SÂRBU \& al. 2014; TOMONIN, 2017; WATSON \& DALLWITZ, 1992].

The ecological preferences of the two species of Nymphaea have some peculiarities in relation to the acidity and trophicity of the water: i) Nymphaea alba prefers both alkaline and weakly acidic waters [MUNTENDAM et al. 1996, SÂRBU et al. 2018] and is eutrophic tolerant [KABÁTOVÁ \& al. 2014], ii) Nymphaea candida prefers alkaline [MUNTENDAM \& al. 1996], mesotrophic and eutrophic waters with a high content of organic matter [NOWAK \& al. 2010]. Both species grow in stagnant or very smoothly flowing, not very deep waters $(0.5-2 \mathrm{~m})$, and Nymphaea candida prefers waters near shore areas [NOWAK \& al. 2010]. In the Danube Delta Nymphaea alba and Nymphaea candida populate the shallow, eutrophic waters of canals, lakes, ponds and swamps [SÂRBU \& al. 2013].

This paper addresses the Nymphaea species in the Danube Delta and aims to:

i. illustrate the morphological identification characters for Nymphaea alba and Nymphaea candida, using material collected from the Danube Delta;

ii. complete the existing information with anatomical-histological data, referring to the organization of the lamina and the petiole;

iii. present and characterize a new variety of the Nymphaea candida taxon from a morpho-anatomical point of view: Nymphaea candida var. undulatifolia.

\section{Material and methods}

The biological material, represented by mature, well-developed plants belonging to the Nymphaea genus, was collected from the Danube Delta (Lake Bodgaproste, Magearu Canal, Bărbos Canal, Letea Canal), during 2012-2015 and 2017-2019, respectively.

The identification of the 2 species of Nymphaea (Nymphaea alba and Nymphaea candida) was performed in situ and was based on the use of morphological identification criteria, mentioned in the literature. The parameters concerned the characteristics of the leaf and the flower: the shape and dimensions of the lamina, the leaf rib, the shape of the flower base, the shape of the flower stalk, the shape of the gynoecium in longitudinal section, the characteristics of the filaments of the internal stamens, the number of lobes of the stigma.

Some of these morphological parameters were also used to describe two varieties, one (Nymphaea alba var. minoriflora), associated with the Nymphaea alba species and cited in the literature as being present in the Danube Delta [SĂVULESCU (ed.), 19521976] and the other (Nymphaea candida var. undulatifolia) associated with the Nymphaea candida species and described for the first time in this paper.

Anatomo-histological observations concerned the leaf (lamina and petiole) and were performed on ten specimens of Nymphaea alba and Nymphaea candida, respectively, and on five specimens of Nymphaea candida var. undulatifolia. Manually cross sections were made in the central part of the lamina on the median nervure, in the marginal part of the lamina and through the petiole, in the median third. Differential and successive colorations of crossed material with Iodine Green and Carmine Alum have been applied [ŞERBĂNESCU-JITARIU \& al. 1983]. All microscopic slides have been analysed with a DOCUVAL optical microscope in normal lights. Photomicrographs have been obtained with a microscope incorporated Nikon D90 digital camera. 


\section{Results}

\section{Nymphaea alba and Nymphaea candida - morphological identification features}

Leaf. In the two Nymphaea species, the mature leaves differ morphologically (Plate I, Figure 1; Plate II, Figure 1). In Nymphaea alba, the blade is ovate to almost subround (Plate I, Figure 5), $30 \mathrm{~cm}$ long and $\sim 26 \mathrm{~cm}$ wide (Table 1). On the lower face of the lamina the nerves are obvious and anastomosed.

In Nymphaea candida, the lamina has an ovate shape, longer than wide ( $28 \mathrm{~cm}$ long and $\sim 19 \mathrm{~cm}$ wide) (Table 1$)$. The nervures are prominent on the lower face and the first pair at the base is curved (Plate II, Figure 5). The petiole is cylindrical and with $40 \%$ thicker in Nymphaea alba compared to Nymphaea candida (Table 2).

The base of the flower. The shape of the flower base is different in the two Nymphaea species: the base is rounded in Nymphaea alba and obtuse 4-edged in Nymphaea candida (Plate I, Figure 2; Plate II, Figure 2; Table 3).

The flower stalk. In cross section the floral stalk is round in Nymphaea alba while in Nymphaea candida, it has several rounded edges (Plate II, Figure 6).

The shape of the stigma. The longitudinal sectioning of the flower, allows to analyze the shape of the stigma. It is flat in shape in Nymphaea alba and obviously concave in Nymphaea candida (Plate I, Figure 3; Plate II, Figure 3).

The lobes of the stigma. The number of lobes of the stigma reflects the number of carpels that participated in the formation of the gynoecium. This number is different for the two Nymphaea species (Table 3): stigma with 14-23 lobes on the edge in Nymphaea alba and stigma with 8-14 lobes on the edge in Nymphaea candida (Table 3).

Filaments of internal stamens. In Nymphaea alba, the filaments of the internal stamens are narrower and narrower, reaching the width of the anthers. These filaments either have the same width along their entire length or are very slightly wider in their median area (Plate I, Figure 4). In Nymphaea candida, the filaments of the internal stamens are wider than the anthers and have the maximum width in the middle (Plate II, Figure 4).

\section{Nymphaea alba and Nymphaea candida - comparative structural aspects}

The histo-anatomical observations made on the two Nymphaea species concerned the leaf (lamina and petiole), a vegetative organ accessible throughout the vegetation period of these plants.

Lamina. The structure of the lamina was analyzed, on cross sections made in the central part of the lamina (on the median nervure and outside it) and in the marginal part of the lamina.

In both plants, the lamina has the characteristic structure of the Nymphaea genus. The lamina is bifacial heterofacial, the mesophile showing a dorsi-ventral organization of the assimilating tissues (adaxial palisadic and abaxial lacunar tissue). The lacunar tissue draws an aerenchyma with polygonal air ducts in the area of the large nervures and with wide canals in the rest of the mesophile. The air ducts are delimited by partition, lamellar, uniseriate walls. The mechanical elements are represented by columnar sclereids with branched top, located in the palisade tissue, by longer or shorter astrosclerids, more or less branched, present in the lacunare tissue and by solitary filiform idioblasts, which often accompany the subepidermal angular collenchyma. The main nervure is prominent at the abaxial face of the lamina, is often accompanied by areas of angular collenchyma and 
contains several collateral conducting bundles, devoid of vascular cambium. The same type of conducting bundles is found in the secondary nervures of different orders, which pass through the mesophile.

The observations made on the histo-anatomical organization of the lamina of Nymphaea alba and Nymphaea candida respectively, highlighted a series of differences, especially from a quantitative point of view (Table 1). In Nymphaea alba, in the central part of the lamina, the median nervure is $\sim 20 \%$ thicker and the mesophilic $\sim 10 \%$ more voluminous, compared to Nymphaea candida (Plate III, Figures 1-4). Palisade tissue is approximately the same thickness in both species $(250.0 \mu \mathrm{m}$ in Nymphaea alba and 260.0 $\mu \mathrm{m}$ in Nymphaea candida). In Nymphaea alba, the palisade tissue represents $\sim 38 \%$ of the mesophilic thickness, and in Nymphaea candida $\sim 44 \%$. The lacunar tissue occupies $62 \%$ of the mesophilic thickness in Nymphaea alba and only 56\% in Nymphaea candida (Table 1, Plate III, Figure 3, Figure 4). In both species, the mesophilus is about $23-24 \%$ thinner at the edge of the lamina than the middle of the lamina. Palisade columnar sclereids are $\sim 10 \%$ longer and $\sim 40 \%$ thicker in Nymphaea candida than in Nymphaea alba (Table 1, Plate III, Figures 5-6).

Petiole. In cross section, the petiole highlights a circular shape. The petiole of Nymphaea alba is thicker (1.5 cm in diameter) compared to the petiole of Nymphaea candida (0.9 $\mathrm{cm}$ in diameter).

The histo-anatomical structure of the petiole is similar in the two species and respects the general organization plan for the Nymphaea genus.

Under the unilayered epidermis, in the multilayered angular collenchyma are present filiform sclereids (rod-shaped sclereids), arranged equidistantly, in series. In the fundamental parenchyma of the petiole, the large, medium and small air ducts are arranged relatively symmetrically.

The vascular system is represented by a modified eustel [SCHNEIDER \& WILLIAMSON, 1993]. The conducting bundles are collateral, single or double and show no vascular cambium. The xylem is represented by few elements and the protoxylematic gap is present. Both single and double conducting bundles were observed in both species. In Nymphaea candida the conducting bundles are $25-30 \%$ more numerous, but their dimensions are slightly smaller (Table 2, Plate IV, Figure 5, Figure 6).

In the petiole of Nymphaea alba, the subepidermal angular collenchyma includes 7-8 layers of cells and has an average thickness of $250.0 \mu \mathrm{m}$ (Table 1, Plate IV, Figure 3). In Nymphaea candida, the area of the collenchyma is $~ 30 \%$ thicker and includes 9-10 layers of cells (Table 1, Plate I, Figure 4). Both Nymphaea alba and Nymphaea candida have large, medium and small air ducts in the structure of the petiole. Both species have 4 large air ducts (1800.0 $\mu \mathrm{m}$ diameter Nymphaea alba and $1500.0 \mu \mathrm{m}$ Nymphaea candida) located in the center of the petiole. Medium-sized air ducts ( $800.0 \mu \mathrm{m}$ diameter) of the petiole of Nymphaea candida are $\sim 35 \%$ more numerous compared the number of average air ducts $(900.0 \mu \mathrm{m}$ diameter) observed in Nymphaea alba (Table 2, Plate IV, Figure 1, Figure 2).

Diaphragmatic tissue was observed in both species, located especially in small but also medium air ducts (Plate IV, Figure 7, Figure 8).

\section{Nymphaea alba var. minoriflora - morphology}

Nymphaea alba var. minoriflora (Barb.) A. et G. Syn. is mentioned as being present in the Danube Delta by SĂVULESCU (ed.) (1952-1976) in the work Flora României. In the period 2012-2015 and 2017-2019, this variety of the Nymphaea alba 
species was observed on the Letea Canal. The plants are short (60-70 cm long), with smaller leaves and flowers than those of Nymphaea alba (Plate V, Figure 1). The leaves have an almost subround blade, with the entire edge (Plate V, Figure 2). The base of the flower is round (Plate V, Figure 3), and the stigma is flat (Plate V, Figure 4), characters which brings it closer to Nymphaea alba.

\section{Nymphaea candida var. undulatifolia - morphology and structure}

Nymphaea candida var. undulatifolia var. nova (Foliis minoribus constat ex typ differt a marginibus obvious undulatis et in floribus minoribus) was identified (Sârbu I.) in the Danube Delta in August 2012, on the Bărbos Canal and on the Letea Canal, at the edge of Nymphaea candida populations (Plate VI, Table 1-3). The presence of the infrataxon was reconfirmed in 2013-2015 and 2017-2019, respectively (Sârbu A.). The nomenclatural type is in the Herbarium of the Botanical Garden "Dimitrie Brândză" in the University of Bucharest, registered with the number 404475.

The plant is a perennial rooted, with a rhizome, with long petiolate floating leaves, a thin, entire, broad-ovate lamina with a wavy edge (Plate VI, Figure 1, Figure 6). The lamina is much smaller (15 cm long and $13 \mathrm{~cm}$ wide) than that of Nymphaea candida and the petiole is $\sim 30 \%$ thinner (Table 1 , Plate VI, Figure 2). The flowers are smaller than those of Nymphaea candida, they are white, 6-6.5 cm in diameter and the flower bud is only 3.8 cm long (Table 3, Plate VI, Figure 4). The base of the flower is obtuse 4-edged and the stigma is concave as in Nymphaea candida, (Plate VI, Figure 3, Figure 5) with 8-16 lobes, respectively. The filaments of the internal stamens are wider than the anthers, as in Nymphaea candida.

The structure of the lamina corresponds to the Nymphaea genus. The median nervure is prominent on the adaxial face and almost as thick as in Nymphaea candida (Table 2, Plate VII, Figure 1). The mesophil is $40 \%$ thinner at the edge of the lamina, compared to its central part, and the palisadic tissue represents $\sim 50 \%$ of the mesophilic thickness (Table 1 , Plate VII, Figure 2). Palisadic columnar sclereids are shorter than those of Nymphaea candida, but vigorous, especially those at the edge of the lamina (45.0 $\mu \mathrm{m}$ thick) (Table 1 , Plate VII, Figure 2, Figure 3). The much thinner edge of the lamina and the presence of a smaller number of columnar sclereids at the top of the lamina could determine to some extent, the undulation of this area, on the surface of the water (Table 1, Plate VII, Figure 2, Figure 3).

The petiole is circular in cross section and highlights all the characteristic elements of a Nymphaea petiole. However, a series of structural features bring it closer to the petiole of Nymphaea candida: the thickness of the subepidermal collenchyma (Table 2, Plate VII, Figure 5), the number of single and double closed collateral type conducting bundles (Table 2), the number of medium-sized air ducts (Table 2, Plate VII, Figure 4).

In this variety, some of the smaller air ducts (200.0-300.0 $\mu \mathrm{m}$ in diameter) are delimited by a layer of larger cells, whose internal tangential walls and lateral walls are obviously thickened (Plate VII, Figure 4, Figure 6). 
Table 1. Analyzed lamina parameters (in cross section): Nymphaea alba, N. candida, N. candida var. undulatifolia.

\begin{tabular}{|c|c|c|c|c|}
\hline & \multirow[b]{2}{*}{ Parameters } & \multicolumn{3}{|c|}{ Measurements/size (average values) } \\
\hline & & $\begin{array}{c}\text { Nymphaea } \\
\text { alba }\end{array}$ & $\begin{array}{l}\text { Nymphaea } \\
\text { candida }\end{array}$ & $\begin{array}{l}\text { Nymphaea } \\
\text { candida var. } \\
\text { undulatifolia }\end{array}$ \\
\hline \multirow{2}{*}{$\begin{array}{l}\text { Dimension of } \\
\text { the lamina }\end{array}$} & Length $(\mathrm{cm})$ & 30.0 & 28.0 & 15.0 \\
\hline & Width (cm) & 26.0 & 19.0 & 13.0 \\
\hline \multirow{7}{*}{$\begin{array}{l}\text { The central part } \\
\text { of the lamina }\end{array}$} & Median rib thickness $(\mu \mathrm{m})$ & 2500.0 & 2000.0 & 2200.0 \\
\hline & $\begin{array}{l}\text { Rib collenchyma thickness } \\
(\mu \mathrm{m})\end{array}$ & 570.0 & 460.0 & 450.0 \\
\hline & Mesophil thickness $(\mu \mathrm{m})$ & 650.0 & 580.0 & 500.0 \\
\hline & Palisadic tissue thickness $(\mu \mathrm{m})$ & 250.0 & 260.0 & 270.0 \\
\hline & Lacuna tissue thickness $(\mu \mathrm{m})$ & 400.0 & 320.0 & 230.0 \\
\hline & Sclereids length $(\mu \mathrm{m})$ & 450.0 & 500.0 & 260.0 \\
\hline & Sclereids thickness $(\mu \mathrm{m})$ & 23.0 & 38.0 & 27.0 \\
\hline \multirow{3}{*}{$\begin{array}{l}\text { The marginal } \\
\text { part of the } \\
\text { lamina }\end{array}$} & Mesophil thickness $(\mu \mathrm{m})$ & 500.0 & 450.0 & 230.0 \\
\hline & Sclereids length $(\mu \mathrm{m})$ & 400.0 & 350.0 & 220.0 \\
\hline & Sclereids thickness $(\mu \mathrm{m})$ & 23.0 & 38.0 & 45.0 \\
\hline
\end{tabular}

Table 2. Analyzed petiole parameters (in cross section): Nymphaea alba, N. candida, N. candida var. undulatifolia.

\begin{tabular}{|c|c|c|c|c|}
\hline \multirow{2}{*}{\multicolumn{2}{|c|}{ Parameters }} & \multicolumn{3}{|c|}{ Measurements/size (average values) } \\
\hline & & Nymphaea alba & $\begin{array}{l}\text { Nymphaea } \\
\text { candida }\end{array}$ & $\begin{array}{l}\text { Nymphaea } \\
\text { candida var. } \\
\text { undulatifolia }\end{array}$ \\
\hline \multicolumn{2}{|l|}{ Diameter of the petiol $(\mathrm{cm})$} & 1.5 & 0.9 & 0.6 \\
\hline \multicolumn{2}{|l|}{ Collenchyma thickness $(\mu \mathrm{m})$} & 250.0 & 350.0 & 320.0 \\
\hline \multicolumn{2}{|l|}{ Number of collenchyma layers } & $7.0-8.0$ & $9.0-10.0$ & $8.0-9.0$ \\
\hline \multirow{2}{*}{ Double conducting bundles } & Number & 8.0 & 10.0 & 8.0 \\
\hline & Length $(\mu \mathrm{m})$ & 1300.0 & 900.0 & 500.0 \\
\hline \multirow{2}{*}{ Simple conducting bundles } & Number & 10.0 & 14.0 & 12.0 \\
\hline & Length $(\mu \mathrm{m})$ & 550.0 & 450.0 & 200.0 \\
\hline \multirow{2}{*}{ Large air ducts } & Number & 4.0 & 4.0 & 4.0 \\
\hline & Diameter $(\mu \mathrm{m})$ & 1800.0 & 1500.0 & 800.0 \\
\hline \multirow{2}{*}{ Medium air ducts } & Number & 10.0 & 14.0 & 12.0 \\
\hline & Diameter $(\mu \mathrm{m})$ & 900.0 & 800.0 & 600.0 \\
\hline
\end{tabular}

Table 3. Analyzed flower parameters: Nymphaea alba, N. candida, N. candida var. undulatifolia.

\begin{tabular}{|l|c|c|c|}
\hline \multirow{2}{*}{\multicolumn{2}{|c|}{ Parameters }} & \multicolumn{2}{c|}{ Measurements/size (average values) } \\
\cline { 2 - 4 } & Nymphaea alba & $\begin{array}{c}\text { Nymphaea } \\
\text { candida }\end{array}$ & $\begin{array}{c}\text { Nymphaea candida } \\
\text { var. undulatifolia }\end{array}$ \\
\hline Length of the floral bud (cm) & 9.0 & 7.0 & 3.8 \\
\hline Flower diameter (cm) & $12.0-13.0$ & $10.0-11.0$ & 6.0 - 6.5 \\
\hline Flower base & rounded shape & 4-edged shape & 4-edged shape \\
\hline Stigma shape & flat shape & concave & concave \\
\hline Number of the stigma lobes & 14.0 - 23.0 & 8.0 - 14.0 & 8.0 - 16.0 \\
\hline Filaments of internal stamens & $\begin{array}{c}\text { narrower or as } \\
\text { wide as the } \\
\text { anthers }\end{array}$ & $\begin{array}{c}\text { wider than the } \\
\text { anthers }\end{array}$ & $\begin{array}{c}\text { wider than the } \\
\text { anthers }\end{array}$ \\
\hline
\end{tabular}




\section{Conclusions}

The paper exemplifies a set of morphological identification features for Nymphaea alba and Nymphaea candida, scientifically accepted and usable in their in situ identification. The use of plant material collected from the Danube Delta, confirms the existence of both taxa in the Danube Delta.

The two species assessed, Nymphaea alba and Nymphaea candida, differ from each other in some structural aspects. These are predominantly dimensional and/or quantitative and target in particular mechanical tissues, assimilative and conductive tissues.

The paper updates the presence of the Nymphaea alba var. minoriflora taxon in the Danube Delta and documents the observations, with current photographic images.

The paper describes a new infrataxon - Nymphaea candida var. undulatifolia var. nova, identified in the Danube Delta and his morphological and structural characteristics, which support its classification on the variety position of the Nymphaea candida taxon.

Based on research conducted in 2012-2019 in the field and in the laboratory, the paper confirms the presence of two species of the Nymphaea genus, namely Nymphaea alba and Nymphaea candida in the Danube Delta and of two varieties of these species: Nymphaea alba var. minoriflora and Nymphaea candida var. undulatifolia.

\section{Notes on contributors}

Anca SÂRBU - is a university professor with a special interest in plant anatomy, flora and vegetation, evaluation and conservation of phytodiversity. She carried out cyto-histological and morpho-anatomical research on protected plants in the Romanian flora, research on aquatic plants in the Danube and Danube Delta, research on plant diversity in Natura 2000 habitat types.

Ion SÂRBU - is a research scientist with a special experience in the plants taxonomy, chorology (vascular plants), phytosociology and habitats. His research focused on the flora and vegetation of Romania, the identification of Natura 2000 sites in Romania, the characterization of the habitat types and plant communities from the most diverse areas of botanical importance in Romania.

Anca-Monica PARASCHIV - is a plant biologist, interested in the study of spontaneous and cultivated plants. She contributed to the development of morpho-anatomical research on some cultivated plants with medicinal value and on some vascular plants from the Danube Delta.

Clara Daniela MIHAI - is a plant biologist, interested in the study of spontaneous plants with emphasis on their anatomy and on the associated histo-anatomical techniques. She was involved in morpho-anatomical researches addressed to spontaneous plant from Bucegi Mountain and Danube Delta.

\section{References}

CIOCÂRLAN V. 1994. Flora Deltei Dunării. București: Edit. CERES, 115 pp.

CIOCÂRLAN V. 2009. Flora ilustrată a României. Pteridophyta et Spermatophyta. Ed. 3. Bucureşti: Edit. CERES, $1141 \mathrm{pp}$.

CIOCÂRLAN V. \& SÂRBU I. 1998. Flora Rezervaţiei Biosferei Delta Dunării, Addenda et corrigenda. Buletinul Grădinii Botanice Univ. Iaşi. 7: 97-109.

KABÁTOVÁ K., VIT P. \& SUDA J. 2014. Species boundaries and hybridization in central - European Nymphaea specie inferred from fenome size and morphometric data. Preslia. 86: 131-154. http://www.preslia.cz/P142Kabatova.pdf (accesed 20.02.2017).

MUNTENDAM J. B., POVEL G. D. E. \& VAN der VELDE G. 1996. Morphometric patterns in the Nymphaea alba - candida complex. Acta Botanica Neerlandica. 45: 279-302. (http://hdl.handle.net/2066/27859 (accessed 20.02.2017).

NOWAK A., NOBIS M., DAJDOK Z., ZALEWSKA-GALOSZ J., NOWAK S., NOBIS A., CZERNIAWSKAKUSZA J., KOZAK M., STEBELA A., BULAR R., SUGIER P., SZLACHETKA A., BENA W., TROJECKA A., PIWOWAECZYK R., ADAMIEC A. \& KRAQCZYK R. 2010. Revision of Nymphaea 


\section{NYMPHAEA L. GENUS IN THE DANUBE DELTA, ROMÂNIA}

candida range - new data on the distribution and habitat preferences of the species in souther Poland. Acta Societatis Botanicorum Poloniae. 79(4): 333-350. https://www.researchgate.net/publication/ 234079058_Revision_of_Nymphaea_candida_range_-new_data_on_the_distribution_and_habitat_ preferences_of_the_species_in_southern_Poland (accessed 20.02.2017).

SĂVULESCU T. (ed.). 1952-1976. Flora României. Vol. III. Bucureşti: Edit. Academiei Române, 637 pp.

SÂRBU A., JANAUER G. A., SCHMIDT-MUMM U. \& EXLER N. 2018. Macrophytes of the Romanian Danube reach and the Danube Delta, pp: 303-333. In: JANAUER G. A., GABERŠČIK A., KVĚT J., GERM M. \& EXLER N. (eds.). 2018. Macrophytes of the River Danube Basin. ACADEMIA, Praha, 407 pp.

SÂRBU A. 2015. Danube Delta - Aquatic and palustre plants. Bucureşti: Edit. CERES, 302 pp.

SÂRBU A., SMARANDACHE D. \& PASCALE G. 2014. Aspecte de citologie şi histologie vegetală. Bucureşti: Edit. CERES, 263 pp.

SÂRBU A., ANASTASIU P. \& SMARANDACHE D. 2013. Habitate acvatice din Delta Dunării - repere în evaluare şi monitorizare. pp: 45-88. In: DOROFTEI M. \& COVALIOV S. (eds.). Manual de Delta Dunării. Tulcea: Edit. Centrul de Informare Tehnologică Delta Dunării, 482 pp.

SÂRBU A., JANAUER G., SCHMIDT-MUMM U., FILZMOSER P., SMARANDACHE D. \& PASCALE G. 2011. Characterisation of the potamal Danube River and the Delta: connectivity determines indicative Macrophyte assemblages. Hydrobiologia. 671(1): 75-93.

SÂRBU A. 2006. Aquatic macrophytes, pp: 133-175. In: TUDORANCEA C. \& TUDORANCEA M. (eds.). 2006. Danube Delta Genesis and Biodiversity. The Netherlands: Backhusy Publishers, 407 pp.

SÂRBU I., ŞTEFAN N. \& OPREA A. 2013. Plante vasculare din România: determinator ilustrat de teren. Bucureşti: Edit. Victor B Victor, 1320 pp.

SCHNEIDER E. L. \& WILLIAMSON P. S. 1993. Nymphaeaceae. pp. 486-493. In: KUBITZKI K., ROHWER J., \& BITTRICH V. (eds.). The Families and Genera of Vascular Plants, Vol. II. Flowering Plants, Magnoliid, Hamamelid and Caryophyllid Families. Springer-Verlag, Berlin, 653 pp. http://link.springer.com/chapter/10.1007/978-3-662-02899-5_57\#page-1 (accessed 20.02.2019).

STRASBURGER E., NOLL F., SCHENCK H., SCHIMPER A. F. W., SITTE P., ZIEGLER H., EHRENDORFER F. \& BRESINSKY A. 1999. Lebrbuch der Botanik für Hochschulen. 34. Aufl. Heidelberg: Spektrum Akad. Verl.

TOMONIN A. C. 2017. Structure of intercellular airspace in the lamine of floating leaves of Nymphaea candida C. Pressl. (Nymphaeaceae): bizarre combination of homobaric and heterobaric types. Wulfenia. 24(2017): 267-274. (https://www.zobodat.at/pdf/Wulfenia_24_0267-0274.pdf, accessed 12.08.2020).

VOLKOVA P. A. \& SHIPUNOV A. B. 2007. Morphological variation in genus Nymphaea L. (Nymphacaceae Juss) of the European Russia. Nordic Journal of Botany. 25(5-6): 329-338. (http://herbc.msu.ru/shipunov/belomor/english/2006/nymph.htn., accessed 20.02.2017).

WATSON L. \& DALLWITZ M. J. 1992. The families of Flowering Plants: description, illustrations, identification and information retrieval. Version: $10^{\text {th }}$ August 2020 . deltaintkey.com/angio/www/nymphaea.htm, accessed 12.08.2020).

How to cite this article:

SÂRBU A., SÂRBU I., PARASCHIV A. M. \& MIHAI D. C. 2020. Nymphaea L. genus in the Danube Delta, România. J. Plant Develop. 27: 3-18. https://doi.org/10.33628/jpd.2020.27.1.3

\section{Plates explanations}

PLATE I Nymphaea alba - morphology

Fig. 1. Nymphaea alba in situ

Fig. 2. Flower base

Fig. 3. Flat stigma

Fig. 4. Filaments of the internal stamens

Fig. 5. Lamina

PLATE II Nymphaea candida - morphology

Fig. 1. Nymphaea candida in situ

Fig. 2. Flower base

Fig. 3. Concave stigma

Fig. 4. Filaments of the internal stamens

Fig. 5. Lamina

Fig. 6. Floral stalk 
Anca SÂRBU \& al.

PLATE III Nymphaea alba \& Nymphaea candida - Lamina structure

Fig. 1. Nymphaea alba - Median rib in cross section (1 - upper epidermis, 2 - air ducts, 3 conducting bundles, 4 - sclereids)

Fig. 2. Nymphaea candida - Median rib in cross section (1 - upper epidermis, 2 - air ducts, 3 conducting bundles, 4 - sclereids)

Fig. 3. Nymphaea alba - Mesophill in the central part of the lamina (1 - upper epidermis, 2 - wide air canals, 3 - sclereids)

Fig. 4. Nymphaea candida - Mesophill in the central part of the lamina (1 - upper epidermis, 2 - wide air canals, 3 - sclereids)

Fig. 5. Nymphaea alba - Mesophill in the marginal part of the lamina (1 - upper epidermis, 2 - wide air canals, 3 - sclereids)

Fig. 6. Nymphaea candida - Mesophill in the marginal part of the lamina (1 - upper epidermis, 2 wide air canals, 3 - sclereids)

PLATE IV Nymphaea alba \& Nymphaea candida - Petiole structure

Fig. 1. Nymphaea alba - Petiole in cross section (1 - air ducts, 2 - sclereids, 3 - conducting bundles)

Fig. 2. Nymphaea candida - Petiole in cross section (1 - air ducts, 2 - sclereids, 3 - conducting bundles)

Fig. 3. Nymphaea alba - Subepidermal collenchyma (1 - epidermis, 2 - angular collenchyma)

Fig. 4. Nymphaea candida - Subepidermal collenchyma (1 - epidermis, 2 - angular collenchyma)

Fig. 5. Nymphaea alba - Simple conducting bundles

Fig. 6. Nymphaea candida - Double conducting bundles

Fig. 7. Nymphaea alba - Petiole in cross section, diaphragmatic tissue is observed (1 - air ducts, 2 diaphragmatic tissue, 3 - conducting bundles)

Fig. 8. Nymphaea alba - Diaphragmatic tissue, detail (1 - air ducts, 2 - diaphragmatic tissue, 3 conducting bundles)

PLATE V Nymphaea alba var. minoriflora - morphology

Fig. 1. Plants in situ

Fig. 2. Leaf and flower

Fig. 3. Flower base

Fig. 4. Flat stigma

PLATE VI Nymphaea candida var. undulatifolia - morphology

Fig. 1. Plants in situ

Fig. 2. Leaf and flower

Fig. 3. Flower base

Fig. 4. Flower: Nymphaea candida (left) and Nymphaea candida var. undulatifolia (right)

Fig. 5. Concave stigma

Fig. 6. Lower face of the lamina

PLATE VII Nymphaea candida var. undulatifolia - Lamina and petiole structure

Fig. 1. Median rib in cross section ( 1 - upper epidermis, 2 - air ducts, 3 - conducting bundles)

Fig. 2. Mesophill in the central part of the lamina (1 - upper epidermis, 2 - air ducts, 3 - sclereids)

Fig. 3. Mesophill in the marginal part of the lamina (1 - upper epidermis, 2 - air ducts, 3 - sclereids)

Fig. 4. Petiole in cross section ( 1 - epidermis, 2 - conducting bundles, 3 - air ducts)

Fig. 5. Petiole, subepidermic collenchyma (1 - epidermis, 2 - angular collenchyma)

Fig. 6. Petiole, air channel delimited by cells with thickened walls (1 - air duct) 


\section{Plate I}

Nymphaea alba - morphology

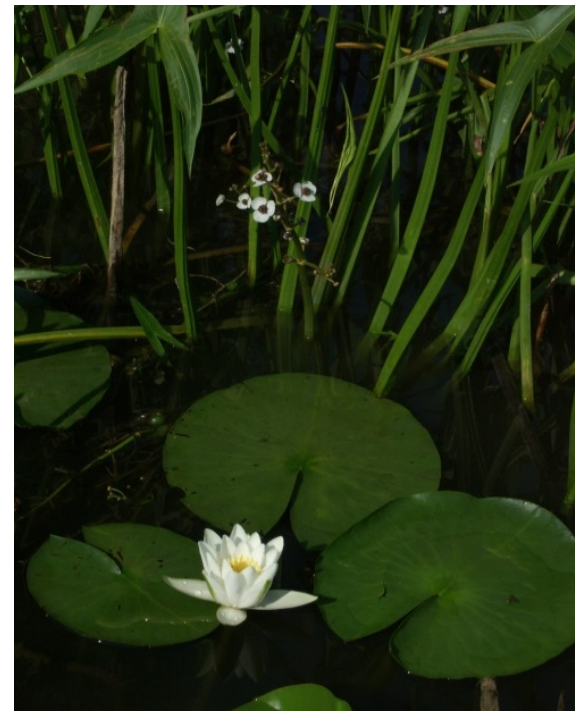

Figure 1

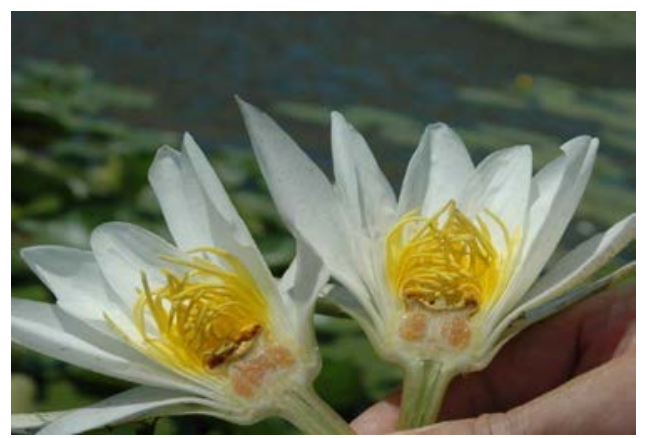

Figure 3

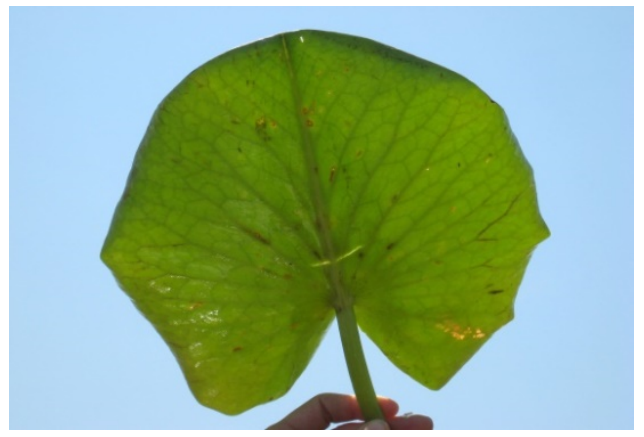

Figure 5

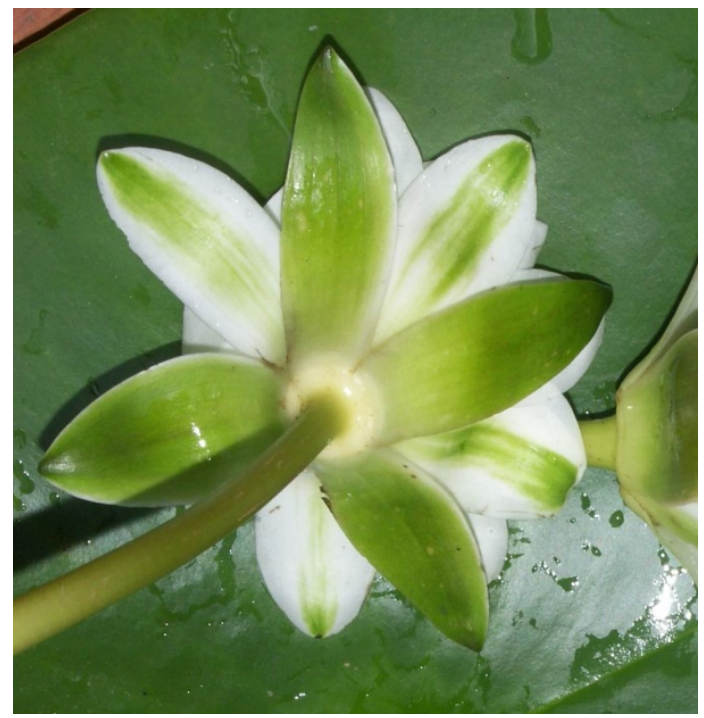

Figure 2

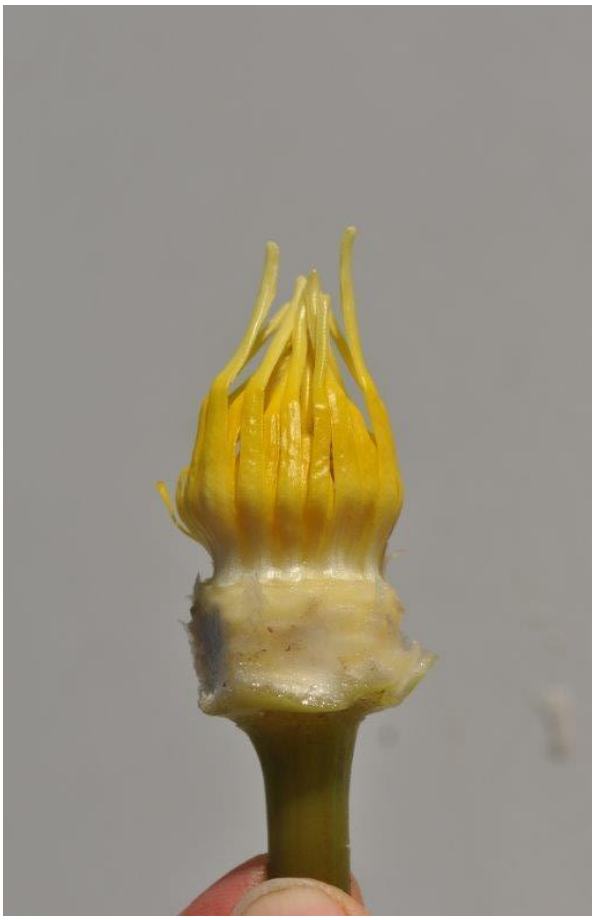

Figure 4 
Anca SÂRBU \& al.

Plate II

Nymphaea candida - morphology

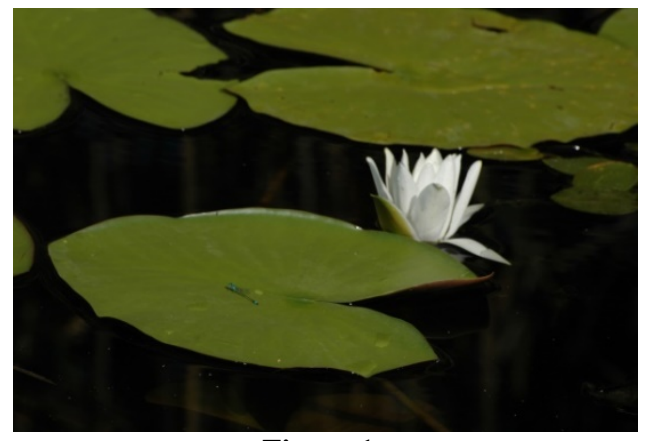

Figure 1

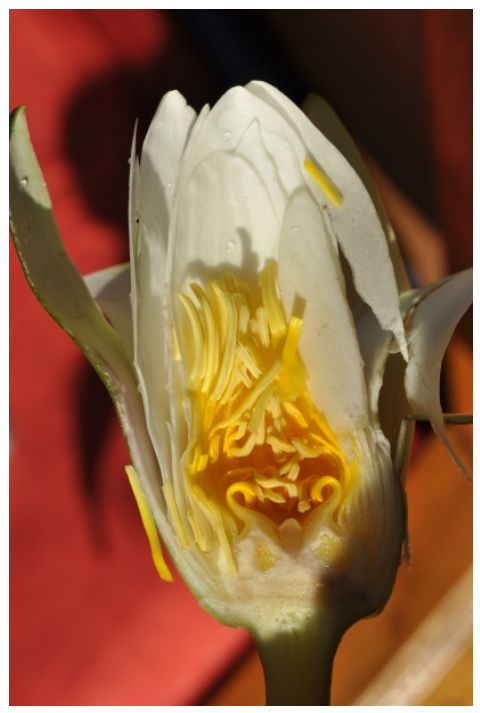

Figure 3

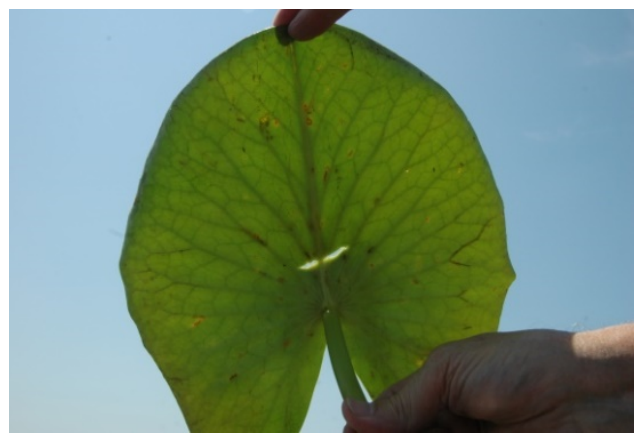

Figure 5

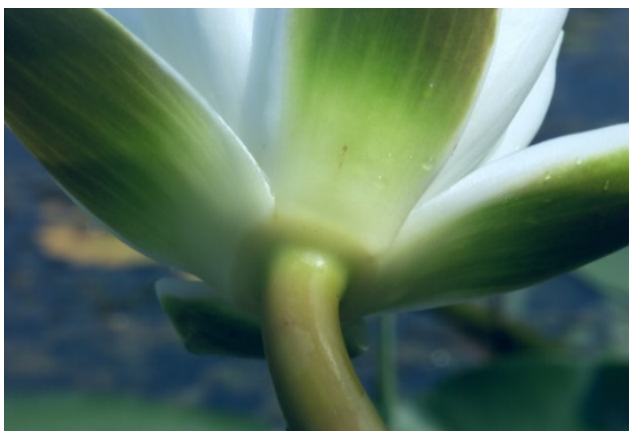

Figure 2

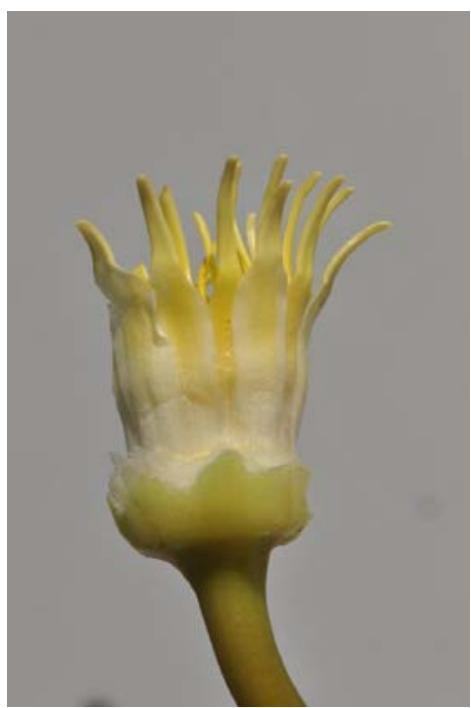

Figure 4

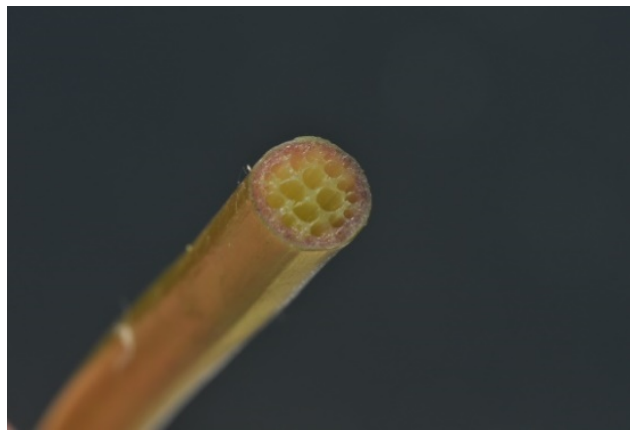

Figure 6 


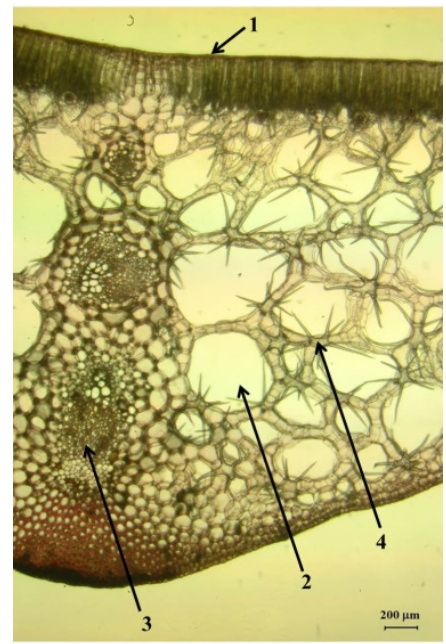

Figure 1

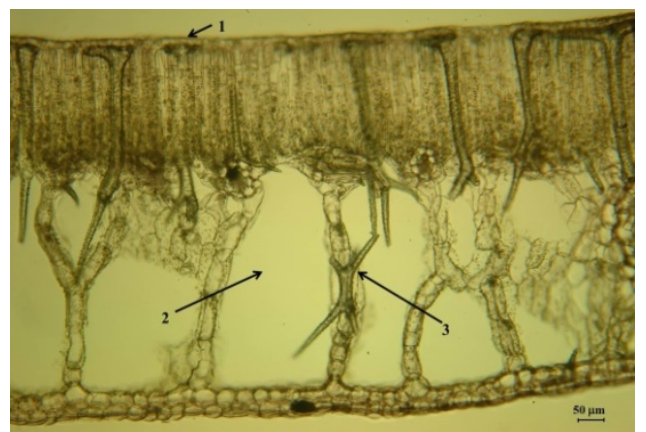

Figure 3

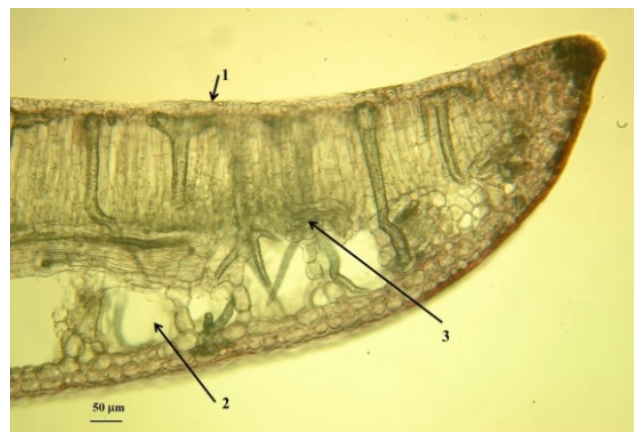

Figure 5

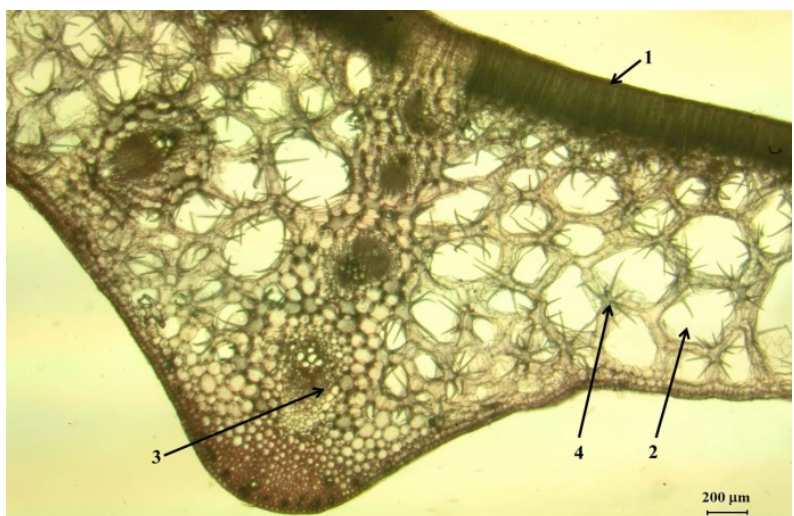

Figure 2



Figure 4

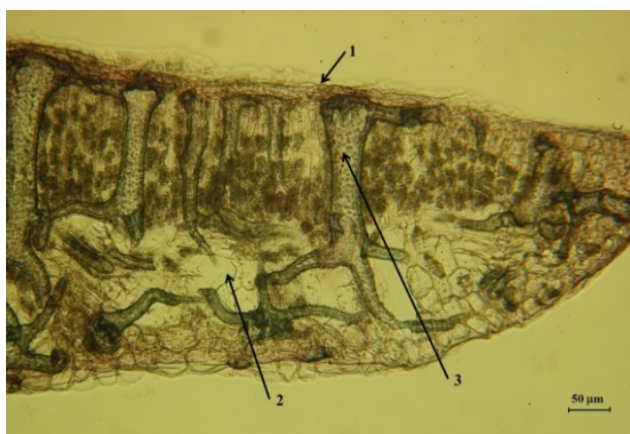

Figure 6 
Anca SÂRBU \& al.

\section{Plate IV}

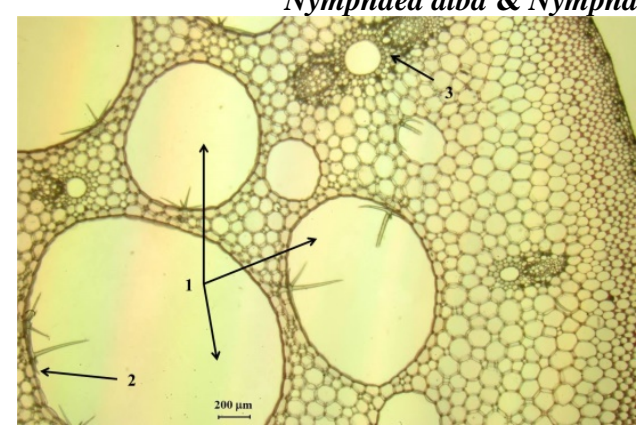

Figure 1

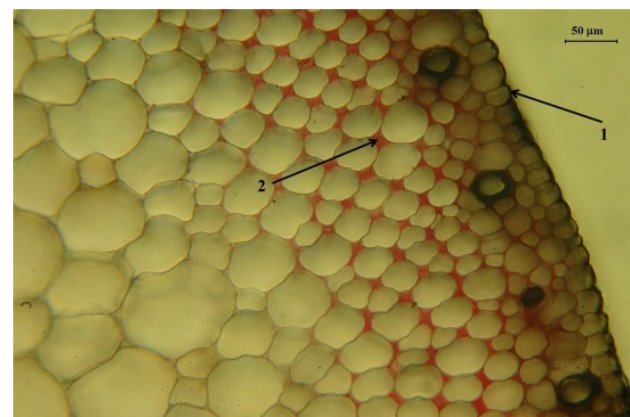

Figure 3

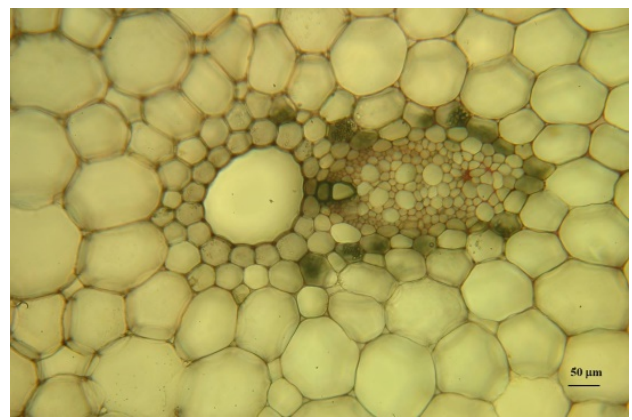

Figure 5

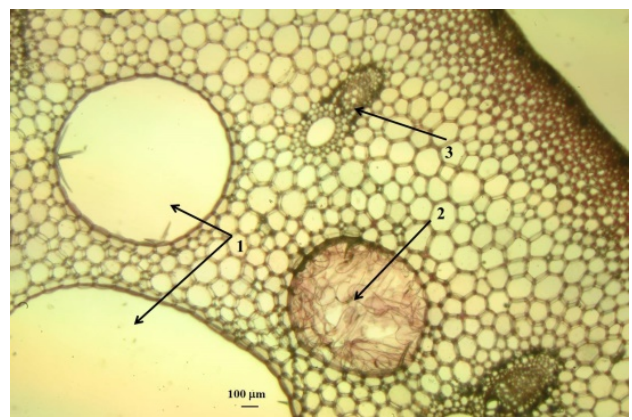

Figure 7



Figure 2



Figure 4

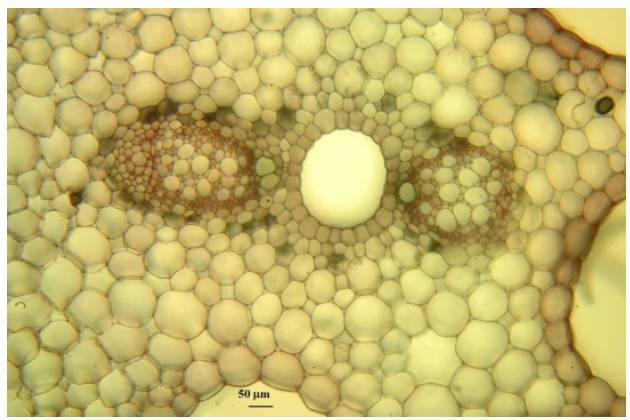

Figure 6

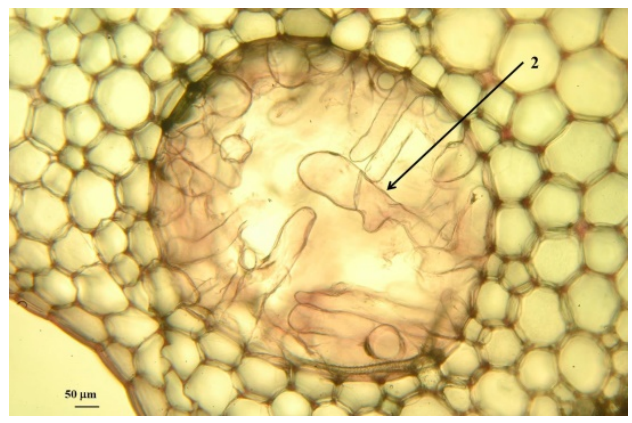

Figure 8 


\section{Plate V}

Nymphaea alba var. minoriflora - morphology

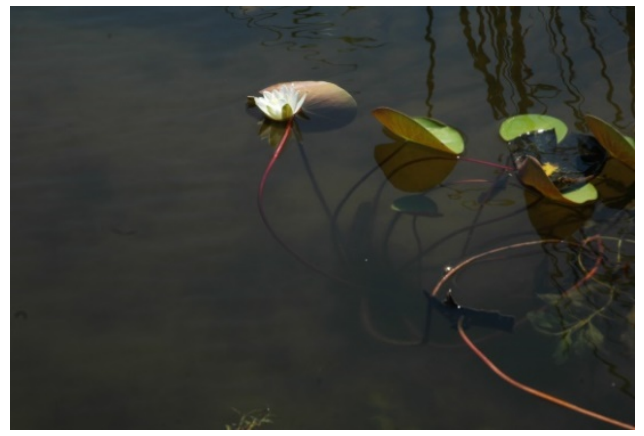

Figure 1

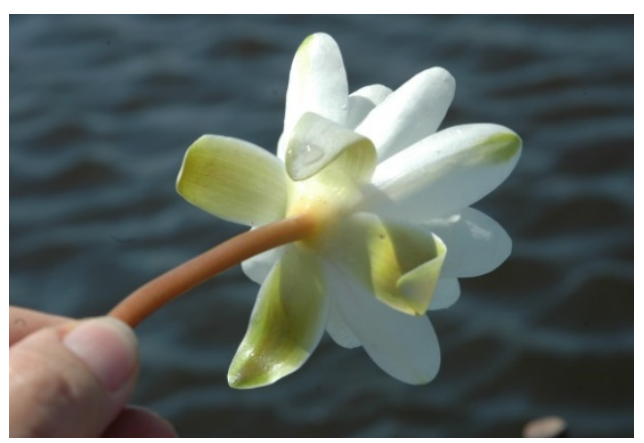

Figure 3

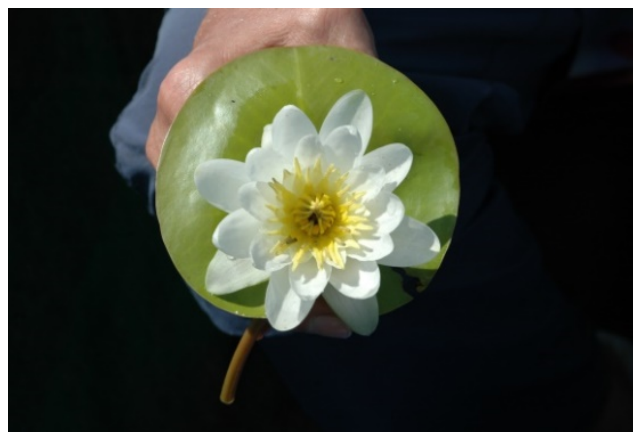

Figure 2

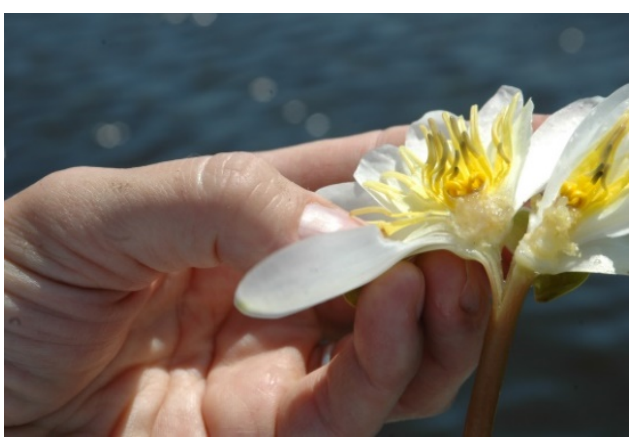

Figure 4 


\section{Plate VI}

Nymphaea candida var. undulatifolia - morphology

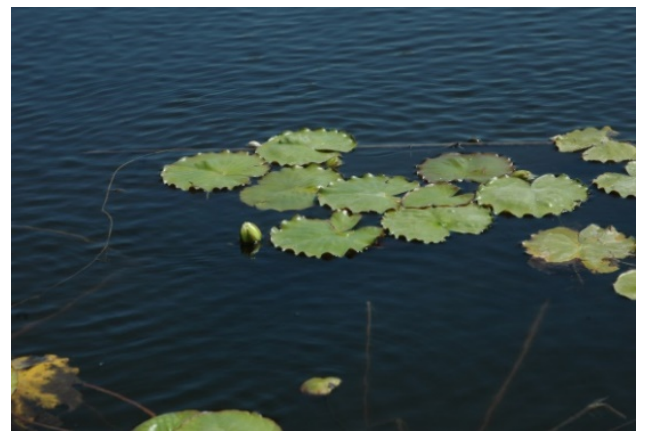

Figure 1



Figure 3

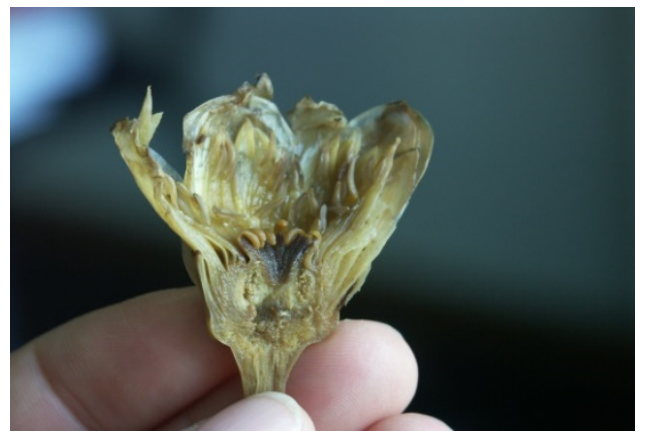

Figure 5

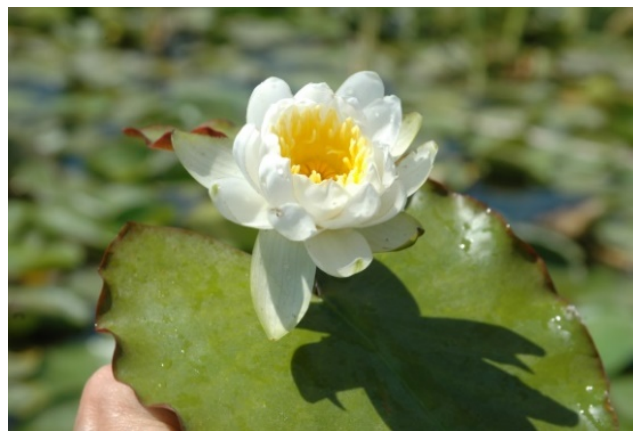

Figure 2

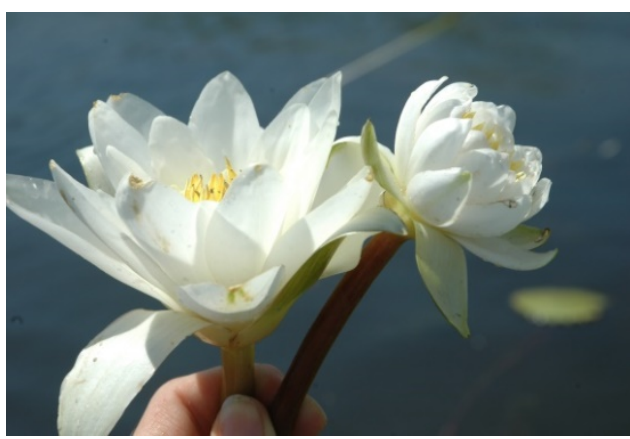

Figure 4

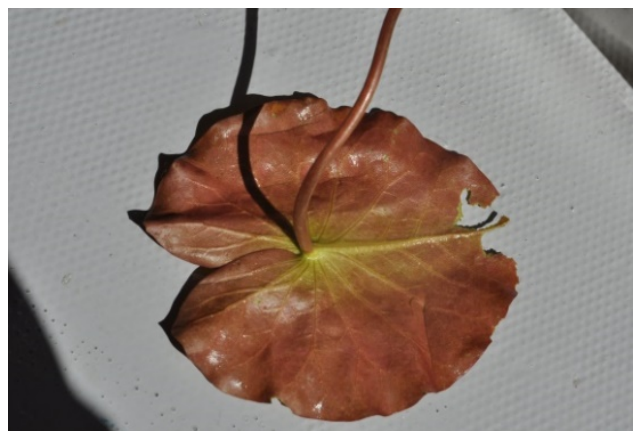

Figure 6 
Nymphaea candida var. undulatifolia - Lamina and petiole structure

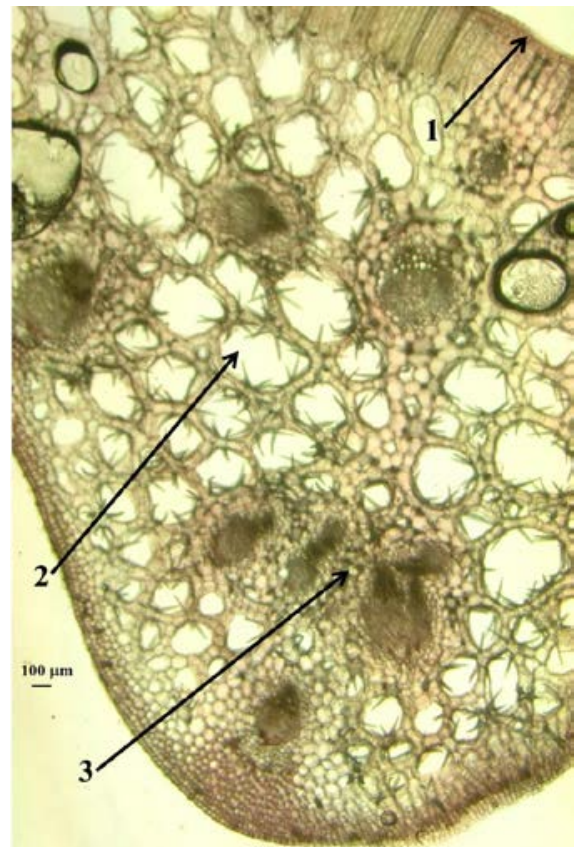

Figure 1



Figure 4

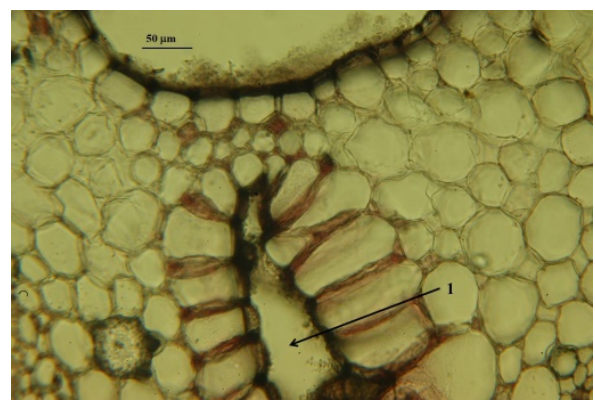

Figure 6

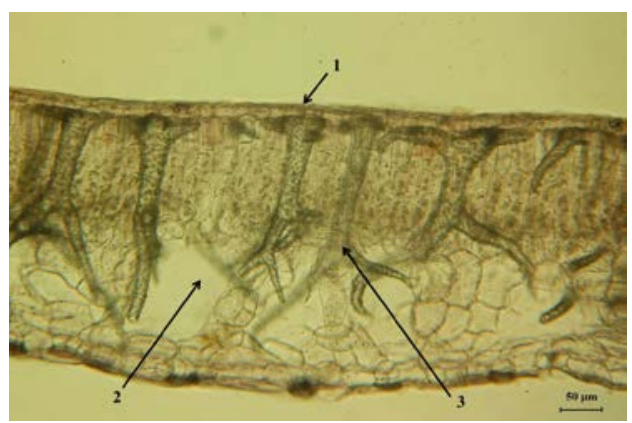

Figure 2

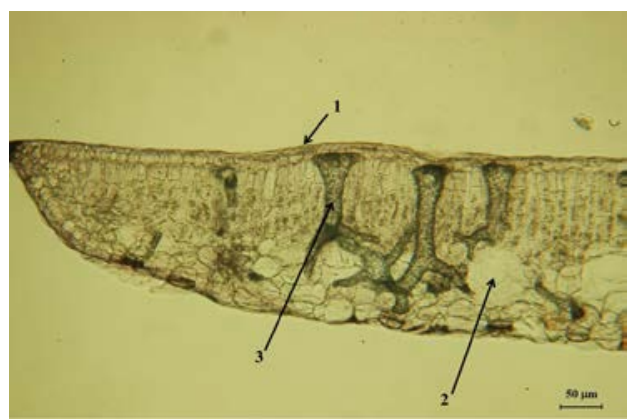

Figure 3

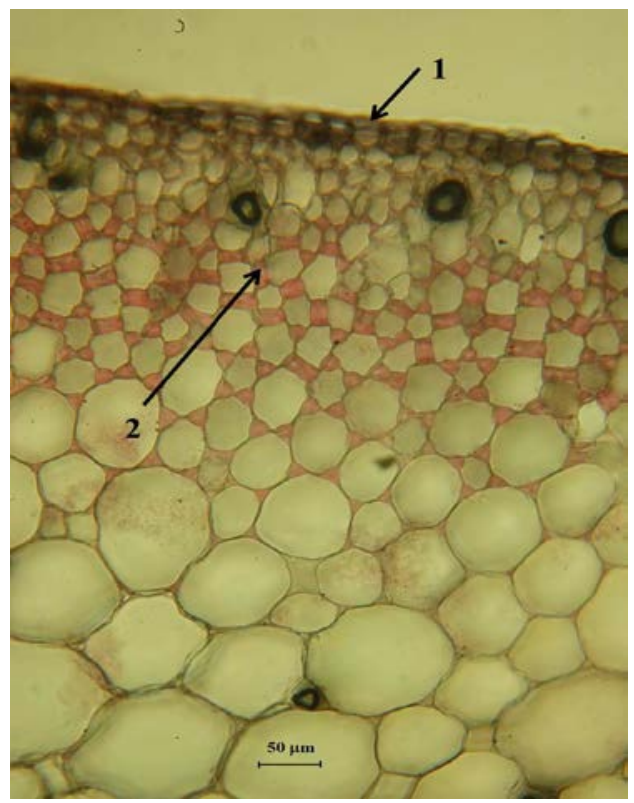

Figure 5 